\title{
Acil Servis ve 112'de Çalışan Sağlık Personelinin Yaşadığı Rol Çatışması ve Belirsizliğinin İş Stresine Etkisi
}

\section{The Effect of Role Conflict and Ambiguity on Work Stress in Health Staff Working in}

Emergency Service and 112

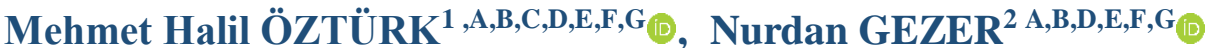 \\ ${ }^{1}$ Pamukkale University, Denizli Vocational School of Health Services Denizli, Turkey \\ ${ }^{2}$ Aydın Adnan Menderes University, Faculity of Nursing, Aydın, Turkey
}

ÖZ

\begin{abstract}
Amaç: Acil servis ve 112'de çalışan personelin yaşadığı rol belirsizliği, rol çatışması ve iş stresinin etkisini incelemektir. Yöntem: Tanımlayıcı-kesitsel bir çalışmadır. Ağustos 2016-Ocak 2017 tarihleri arasında iki acil servis ve 112 istasyonlarında çalışan 188 sağlık personeli katılmıştır. Veriler "kişisel bilgi formu", "rol çatışması ve rol belirsizliği ölçeği" ile "iş stresi ölçeği” kullanılarak toplanmıştır.

Bulgular: Evlilerin, mesleğini sevmeyenlerin, mesleki kanun ve yönetmelik bilgisine sahip olmayanların, mesleki görev ve sorumluluk bilgisine kısmen sahip olanların daha çok rol belirsizliği, mesleğini sevmeyen ve 25-30 yaş aralığındaki kişilerin daha çok rol çatışması, kadınların, mesleğini sevmeyenlerin, 25-30 yaş aralığındaki ve mesleki kanun ve yönetmelik bilgisine kısmen sahip olanların daha çok iş stresi yaşadığı sonucuna ulaşılmıştır.

Sonuç: İş stresi, rol çatışması ve belirsizliğinin birbirini etkilediği sonucuna ulaşılmıştır.
\end{abstract}

Anahtar Kelimeler: Çatışma, Belirsizlik, Stres, Acil servis, 112.

\section{ABSTRACT}

Objective: To investigate the effect of role conflict and ambiguity on work stress in health staff working in emergency service and 112.

Methods: This descriptive cross-sectional study was planned between August 2016 and January 2017. 188 people working at 112 stations and two emergency service participated in the study. Data were collected using "personal information form", "role conflict and role ambiguity scale" and "work stress scale".

Results: It has been found more role ambiguity of married people, more role conflict of who do not like their profession and who have between 25-30 years of age, more work stress of women who do not like their profession, women who have between 25-30 years of age.

Conclusion: Role ambiguity and conflict, work stress experienced by employees affect each other.

Key words: Conflict, Ambiguity, Stress, Emergency department, 112.

\section{INTRODUCTION}

Health service is a service sector that requires intensive efforts to provide services to sick people. The problems experienced in this sector and the unsuccessful management of the labor force have extremely high human and economic costs (1). In order to increase the

Corresponding Author: Mehmet Halil ÖZTÜRK

Pamukkale Üniversitesi Kınıklı Yerleşkesi/Denizli Sağlık Hizmetleri Meslek Yüksekokulu / D Blok

20070/Kın1kl1/DENIZLİ, TÜRKIYE

mehmet_ozturk@pau.edu.tr

Received: 23.05.2020 - Accepted: 15.11.2020

* This study is a master thesis of Adnan Menderes University, Institute of Health Sciences, completed in 2017. Verbal

presentation was made in 1rd international health science and life congress (Ihslc 2018), Burdur, TURKEY.

Yazar Katkıları: A) Fikir/Kavram, B) Tasarım, C) Veri Toplama ve/veya İşleme, D) Analiz ve/veya Yorum, E) Literatür

Taraması, F) Makale Yazımı, G) Eleştirel İnceleme 
efficiency and effectiveness of service delivery, it is absolutely necessary for health workers to work in an environment where they can perform their roles professionally within the framework of a division of work in accordance with their knowledge, training and skills. In order to provide effective and efficient health services in the institution, teamwork approach should be adopted (2). The rapid technological developments, expectations and needs of patients, demand and legal changes in health services inevitably affect the roles of employees in the institution (3).

The role is the set of behaviors expected from individuals working in an organization. If a person who needs to perform a role cannot fulfill the desired roles for various reasons after having detailed the priorities of the expected role, then they experience role ambiguity when they do not have sufficient skills and knowledge of the role they need to perform. If people are exposed to a high level of role conflict and role ambiguity. In studies, people has been shown that increased feelings of hostility, fear, restlessness and stress cause a decrease in selfconfidence and organizational productivity (4).

Stress can be defined as a reaction or condition that occurs when a person is physically and mentally exposed to a challenge that exceeds the coping capacity (5). Work stress is generally defined by various and different aspects of the work area in the institution. Factors such as time pressure, difficult patients, heavy responsibilities, difficulties in computing, insufficient resources and working alone are highly effective in job stress (6).

Serious problems caused by job stress in health care workers lead to negativities that affect service provision such as absenteeism, decrease in job efficiency and job satisfaction $(7,8)$. Health care units providing emergency aid are the units where work stress is extremely intense. It is stated that employees in these units are exposed to more stress factors than healthcare professionals working in different units. Unlike healthcare professionals working in different units, they have to deal with various aggressions, dangers and sudden traumatic experiences such as workplace violence (9-11). These traumatic experiences of employees in emergency healthcare units are closely related to the decrease in job satisfaction, role conflict, job stress, role ambiguity and reduction in professional and organizational commitment (1113).

\section{Aim}

The aim of this study was to determine the effects of role conflict and role ambiguityty on work stress and factors affecting work stress in emergency department and 112 health personnel.

\section{MATERIALS AND METHOD}

\section{Type of the Study}

This descriptive cross-sectional study was planned between August 2016 and January 2017. 


\section{The Universe and the Sample of the Research}

\section{Inclusion Criteria}

The population of the study consisted of 278 health personnel working in Pamukkale University Hospital emergency service, Servergazi State Hospital emergency service and 12 112 Emergency Health Services Stations in Denizli province in Turkey. It was aimed to reach the whole population which was not taken into sample calculation. Questionnaire filling was done by face to face interview method. People who were randomly choosen during the application, who did not volunteer to participate in the study and who were on leave between August 2016 and January 2017 were excluded from the study. It was found that 47 people did not complete the questionnaire appropriately and 43 did not want to participate in the study. For this reason, a survey of 188 people was included in the data analysis.

\section{Data Collection Tools}

Personal information form, role conflict and role ambiguity scale and, work stress scale are the parts of survey application.

\section{Personal Information Form}

The personal information form consisted of two sections including sociodemographic and professional information. It consisted of 12 questions related to sociodemographic information such as gender, age, education and marital status of the individuals and the profession of the participants, the unit, weekly working time, professional working year, factors that may cause occupational stress, liking the profession, occupational law and regulation information, professional duties and responsibilities.

\section{Role Conflict and Role Ambiguity Scale}

Role Conflict and role ambiguity scale; was developed by Rizzo, House and Lirtzman (14) in 1970 and the validity and reliability were made by Yıldırım (15) in Turkey in 1996. The Cronbach's alpha value of the scale was 0.81 for role conflict and 0.72 for role ambiguity. In our study, Cronbach's alpha value was found to be 0.67 for role conflict and 0.71 for role ambiguity. The scale is seven likert type scale consisting of two sub-dimensions and 14 items (15).

\section{Work Stress Scale}

The cronbach's alpha value of the scale developed by Baltaş and Baltaş was found to be 0.83 . The job stress scale consists of 15 questions and five likert type scoring ( $1=$ never, $2=$ rarely, $3=$ sometimes, $4=$ often, 5=almost always). The total score obtained from the evaluation of the scale is divided into 15 and the average score of the individual is obtained. A, $\mathrm{B}, \mathrm{E}$ and $\mathrm{F}$ are evaluated as stress levels that may affect productivity and threaten health (16). 


\section{Data Analysis}

Statistical analysis of the data was performed using SPSS (license number: 10241440) 15.0 Windows package program. Kolmogrov Simirnov and Shapiro-Wilk normality analysis, Q-Q plot and histogram graphs were used to determine whether the data were normally distributed or not. Since the research did not show a normal distribution; It was evaluated as a nonparametric study. Mann Whitney $U$ was used when two variables were compared, and Kruskal Wallis, chi-square and correlation analysis were used when more than two variables were compared. Multiple linear regression analysis with stepwise method was used in the selection of variables affecting role conflict, role ambiguity and work stress scores. The $\mathrm{p}<0.05$ result was used to determine the level of significance.

\section{The Ethical Aspect Of Research}

During the research, the Human Rights Helsinki Declaration was adhered to. Written permission was obtained from the institutions where research data was collected by applying an information form containing the purpose and scope of the study. Ethics Committee approval was received (Number: 53043469-050.04.04 - Date and Number of Documents: 09/09/2016E.37542).

\section{RESULTS}

Table 1 shows the distribution of the emergency department participating in the study and the health personnel working in 112 according to the descriptive characteristics. The mean age of the participants was $32.08 \pm 8.32$ (min:19-max:61). 38.8\%(n=73) of the participants were between the ages of $31-40,53.7 \%(n=101)$ were males and $68.6 \%(n=129)$ were married. When the graduation status is examined, $35.1 \%(\mathrm{n}=66)$ are associate degree graduates. The participants consisted of $26.6 \%(n=50)$ nurses, $23.4 \%(n=44)$ emergency medical technicians and $19.1 \%(n=36)$ physicians. Looking at the unit studied, 54.8\% $(n=103)$ of the participants worked in emergency health stations and $45.2 \%(\mathrm{n}=85)$ of them worked in emergency services. $21.3 \%(n=40)$ were working 40 hours or less. $78.7 \%(n=148)$ of those working for 41 hours or more per week. The average weekly working time was $51.21 \pm 10.47$ hours (min:24-max:80). When the working period of the institution is examined, it is seen that $42 \%(n=79)$ of the participants worked for 1-6 years. The average working years in the institution is $9.39 \pm 7.28$ (min:1-max:40) years. It was found that $88.8 \%(n=167)$ of the employees liked their profession. It was found that $65.4 \%(n=123)$ of the employees had partially knowledge of professional law and regulation and $78.8 \%(\mathrm{n}=148)$ had professional duty and responsibility information.

Married people, people who do not like their profession, people who do not have professional law and regulation knowledge, people who have partial knowledge of their professional duties and responsibilities experience more role ambiguity. It was concluded that people who do not like their profession and health personnel between 25-30 years of age have more role conflicts. It was concluded that women, people who do not like their profession, health personnel between 25-30 years of age and people who have partial knowledge of professional laws and regulations experience more work stress.

In Table 2, 53.2\% of the emergency personnel and 112 health personnel working in the emergency department see workload as the most important factor in work stress. 
Table 1. Distribution of The Participants in Terms of Descriptive Statistics and Comparison of The Characteristics With Obesity Prejudice Scale (n=229)

\begin{tabular}{|c|c|c|c|c|}
\hline Characteristic & Number & Percent & $\mathbf{X} \pm \mathbf{S S}$ & Test, \\
\hline \multicolumn{5}{|l|}{ Gender } \\
\hline Female & 224 & 97.8 & $78.71 \pm 11.35$ & $\mathrm{~F}=1.774$ \\
\hline Male & 5 & 2.2 & $72.20 \pm 7.53$ & $\mathrm{p}=0.172$ \\
\hline \multicolumn{5}{|l|}{ Marital Status } \\
\hline Maried & 157 & 68.6 & $79.19 \pm 10.87$ & $\mathrm{t}=1.224$ \\
\hline Single & 72 & 31.4 & $77.22 \pm 712.19$ & $\mathrm{p}=0.222$ \\
\hline \multicolumn{5}{|l|}{ Monthly Income } \\
\hline Income higher than expenditure & 38 & 16.6 & $77.74 \pm 8.99$ & $\mathrm{~F}=0.312$ \\
\hline Income equal to expenditure & 136 & 59.4 & $79.06 \pm 11.64$ & $\mathrm{p}=0732$ \\
\hline Income lower than expenduture & 55 & 24.0 & $77.95 \pm 12.02$ & \\
\hline \multicolumn{5}{|l|}{ Level of Education } \\
\hline High school & 71 & 31.0 & $78.72 \pm 11.14$ & $\mathrm{~F}=1.265$ \\
\hline Associate degree & 85 & 37.1 & $77.19 \pm 11.32$ & $\mathrm{p}=0.284$ \\
\hline Undergraduate and graduate & 73 & 31.9 & $80.06 \pm 11.43$ & \\
\hline \multicolumn{5}{|l|}{ Profession } \\
\hline Nurse & 104 & 45.4 & $78.84 \pm 10.72$ & $\mathrm{t}=0.322$ \\
\hline Midwife & 125 & 54.6 & $78.35 \pm 11.82$ & $\mathrm{p}=0.748$ \\
\hline \multicolumn{5}{|l|}{ BMI and range $\left(\mathrm{kg} / \mathrm{m}^{2}\right)$} \\
\hline Slim (18.49 and less) & 8 & 3.5 & $82.00 \pm 8.94$ & \multirow{4}{*}{$\begin{array}{c}F=2.551 \\
p=0.56\end{array}$} \\
\hline Normal weight (18.5- 24.99) & 122 & 53.3 & $77.73 \pm 10.72$ & \\
\hline Overweight (25.0-29.99) & 66 & 28.8 & $77.42 \pm 11.99$ & \\
\hline Obese $(>30.0)$ & 33 & 14.4 & $83.15 \pm 11.73$ & \\
\hline \multicolumn{5}{|c|}{ Participants' assesment of their body structure } \\
\hline Slim & 8 & 3.5 & $81.63 \pm 8.81$ & $\mathrm{~F}=0.595$ \\
\hline Normal & 106 & 46.3 & $77.88 \pm 11.45$ & \multirow[t]{2}{*}{$\mathrm{p}=0.704$} \\
\hline Slightly overweight & 52 & 22.7 & $77.46 \pm 10.38$ & \\
\hline Overweight & 41 & 17.9 & $80.00 \pm 12.50$ & \\
\hline Fat & 17 & 7.4 & $81.00 \pm 11.26$ & \\
\hline Obese & 5 & 2.2 & $80.0 \pm 13.44$ & \\
\hline \multicolumn{5}{|l|}{ Attitude towards obese invidiuals } \\
\hline Prejudiced & 13 & 5.7 & $75.62 \pm 14.59$ & $\mathrm{~F}=1.147$ \\
\hline Unprejudiced & 176 & 76.9 & $79.18 \pm 11.30$ & $\mathrm{p}=0.319$ \\
\hline Undecided & 40 & 17.5 & $76.88 \pm 10.10$ & \\
\hline \multicolumn{5}{|c|}{ Presence of obese individuals in the family } \\
\hline No & 135 & 59.0 & $78.61 \pm 11.19$ & \multirow{2}{*}{$\begin{array}{l}F=0.954 \\
p=0.415\end{array}$} \\
\hline Mother & 37 & 16.2 & $76.57 \pm 9.73$ & \\
\hline Father & 6 & 2.6 & $75.33 \pm 10.37$ & \\
\hline Other (sibling, child, uncle, aunt) & 51 & 22.3 & $80.31 \pm 12.870$ & \\
\hline \multicolumn{5}{|c|}{ The Cut-Off Points of The Obesity Prejudice Scale } \\
\hline Unprejudiced (68.00 and lower) & 37 & 16.2 & & \\
\hline Inclined to prejudiced (68.01-84.99) & 129 & 56.3 & & \\
\hline Prejudiced ( 85.00 and higher) & 63 & 27.5 & & \\
\hline Obesity Prejudice Scale Total Scor & & \multicolumn{3}{|c|}{$78.57 \pm 11.31$ (min:51, max:115) } \\
\hline Age & & & $32.99 \pm 8.10(\min : 1$ & $63)$ \\
\hline Years in the profession & & & $9.14 \pm 9.07(\mathrm{~min}$ & $: 42)$ \\
\hline BMI and range $\left(\mathrm{kg} / \mathrm{m}^{2}\right)$ & & & $25.24 \pm 4.63(\min : 16.5$ & :46.99) \\
\hline
\end{tabular}

When the work stress scale is examined in Table 3; It was seen that 38.3\% $(n=72)$ health personnel working in the emergency department and 112 participated in the study experienced the level of stress which attracted to the person despite the high level of stimulus and responsibility.

In Table 4, there was a weak positive relationship between role conflict and role ambiguity, an intermediate negative relationship between role conflict and work stress, a very weak negative relationship between role conflict and education level. There was a weak negative correlation between role ambiguity and work stress. There was a very weak positive 
correlation between work stress and education level. A very weak negative correlation was found between education level and weekly working time. There was a very weak negative correlation between age and work stress, and a weak negative correlation between age and weekly working time.

Table 2. The most important factors causing professional stress.

\begin{tabular}{lcc}
\hline & $\mathbf{N}$ & $\mathbf{\%}$ \\
\hline Excessive workload & 100 & 53.2 \\
\hline Lack of staff & 75 & 39.9 \\
\hline Problems arising from the administration & 72 & 38.3 \\
\hline Length of the run time & 32 & 17 \\
\hline Staffing & 17 & 9 \\
\hline Other & 16 & 8.5 \\
\hline * Multiple options are checked & $\mathbf{3 1 2}$ & $\mathbf{1 0 0}$
\end{tabular}

Table 3. Percentage averages of work stress of health personnel working in emergency services and 112

\begin{tabular}{lccc}
\hline Work stress scale values & Range & $\mathbf{N}$ & $\mathbf{\%}$ \\
\hline A (1. Group) & $3.5-4.0$ & 14 & 7.4 \\
\hline B (2. Group) & $1.0-1.3$ & 4 & 2.1 \\
\hline C (3. Group) & $1.4-1.9$ & 24 & 12.8 \\
\hline D (4. Group) & $2.0-2.5$ & 54 & 28.7 \\
\hline E (5. Group) & $\mathbf{2 . 6 - 3 . 1}$ & $\mathbf{7 2}$ & $\mathbf{3 8 . 3}$ \\
\hline F (6. Group) & $3.2-3.4$ & 20 & 10.6 \\
\hline TOTAL & & $\mathbf{1 8 8}$ & $\mathbf{1 0 0 . 0}$
\end{tabular}

Table 4. Relation between role ambiguity, role conflict, work stress and affecting factors experienced by health personnel working in emergency services and 112

\begin{tabular}{|c|c|c|c|c|c|c|}
\hline Age & & $\begin{array}{l}\text { Role } \\
\text { conflict }\end{array}$ & $\begin{array}{l}\text { Role } \\
\text { ambiguity }\end{array}$ & $\begin{array}{l}\text { Work } \\
\text { stress } \\
\end{array}$ & Graduation & $\begin{array}{l}\text { Weekly } \\
\text { work hour }\end{array}$ \\
\hline \multirow[t]{2}{*}{ Role Conflict } & $\mathrm{r}$ & & & & & \\
\hline & $\mathrm{p}$ & & & & & \\
\hline \multirow[t]{2}{*}{ Role Ambiguity } & $\mathrm{r}$ &, $355(* *)$ & & & & \\
\hline & $\mathrm{p}$ &, 000 & & & & \\
\hline \multirow[t]{2}{*}{ Work stress } & $\mathrm{r}$ &, $609(* *)$ &,$- 389(* *)$ & & & \\
\hline & $\mathrm{p}$ &, 000 &, 000 & & & \\
\hline \multirow[t]{2}{*}{ Graduation } & $\mathrm{r}$ &,$- 200(* *)$ &,- 009 &, $166(*)$ & & \\
\hline & $\underline{\mathrm{p}}$ &, 006 &, 898 &, 023 & & \\
\hline Weekly work & $\mathrm{r}$ &,- 070 &, 115 &, 057 &,$- 163(*)$ & \\
\hline hour & $\mathrm{p}$ & ,342 & ,118 & , 440 & ,025 & \\
\hline \multirow[t]{2}{*}{ Age } & $\mathrm{r}$ &, 172 &, 010 &,- 178 &,- 043 &,- 277 \\
\hline & $\mathrm{p}$ &, 018 & ,889 &, 015 &, 554 &, 000 \\
\hline
\end{tabular}

$*$ Correlation is significant at 0.05 level.
$* *$ Correlation is significant at 0.01 level. 
In the regression analysis in table 5, there was a positive relationship between role conflict score and role ambiguity score and a negative correlation with work stress score ( $p<0.05$ ). Role conflict was found to be affected $38 \%$ of role uncertainty and $37 \%$ of work stress. In addition, there was a positive correlation between role ambiguity score and liking profession, knowledge of law and regulation; There was a negative correlation between work stress score ( $\mathrm{p}<0.005)$. It was concluded that role ambiguity affects $26 \%$ of the liking of the profession, $21 \%$ of knowledge of laws and regulations and $15 \%$ of work stress. A negative correlation was found between work stress score and role conflict, role ambiguity, knowledge of law and regulation ( $\mathrm{p}<0.005)$. It was found that $43 \%$ of insufficiency of Law and Regulation Information, $40 \%$ of role ambiguity, $37 \%$ of role conflict affected work stress.

Table 5. Regression values of role ambiguity, role conflict and work stress among health personnel working in emergency services and 112 by dependent and independent variables

Factors affecting the role conflict of health personnel working in emergency services and 112

\begin{tabular}{|c|c|c|c|c|c|c|c|}
\hline \multirow[b]{2}{*}{ Factors } & \multirow[b]{2}{*}{$\beta$} & \multirow[b]{2}{*}{ Std. Error } & \multicolumn{5}{|c|}{ \% 95 Confidence Interval } \\
\hline & & & $\mathbf{t}$ & $p$ & Lower & Top & $\mathbf{R}^{2}$ \\
\hline $\begin{array}{l}\text { Role Conflict Scale } \\
\text { (Constant) }\end{array}$ & 4,927 &, 508 & 9,707 & ,000 & 3,926 & 5,929 & \\
\hline Work Stress Scale &,- 801 & ,090 & $-8,871$ & ,000 &,- 979 &,- 623 & ,370 \\
\hline $\begin{array}{l}\text { Role Ambiguity } \\
\text { Scale }\end{array}$ &, 151 & ,068 & 2,236 & ,027 & ,018 & ,284 & ,387 \\
\hline
\end{tabular}

Factors affecting the role ambiguity of health personnel working in emergency services and 112

\begin{tabular}{|c|c|c|c|c|c|c|c|}
\hline \multirow[b]{2}{*}{ Factors } & \multirow[b]{2}{*}{$\boldsymbol{\beta}$} & \multirow[b]{2}{*}{ Std. Error } & \multicolumn{5}{|c|}{ \% 95 Confidence Interval } \\
\hline & & & $\mathbf{t}$ & $p$ & Lower & Top & $\mathbf{R}^{2}$ \\
\hline $\begin{array}{l}\text { Role Ambiguity Scale } \\
\text { (Constant) }\end{array}$ & 6,721 & ,237 & 28,354 & ,000 & 6,253 & 7,188 & \\
\hline Work Stress Scale &,- 469 &,- 089 & $-5,272$ & ,000 &,- 644 &,- 293 &, 151 \\
\hline $\begin{array}{l}\text { Knowledge of } \\
\text { Professional Law } \\
\text { and Regulations }\end{array}$ &,- 905 & ,224 & $-4,040$ & ,000 & $-1,347$ &,- 463 & 211 \\
\hline Loving Profession &,- 633 &, 165 & $-3,826$ & ,000 &,- 959 &,- 306 & 269 \\
\hline
\end{tabular}

Factors affecting the work stress of health personnel working in emergency services and 112

\begin{tabular}{|c|c|c|c|c|c|c|c|}
\hline \multirow[b]{2}{*}{ Factors } & \multirow[b]{2}{*}{$\boldsymbol{\beta}$} & \multirow[b]{2}{*}{ Std. Error } & \multicolumn{5}{|c|}{$\% 95$ Confidence Interval } \\
\hline & & & $\mathbf{t}$ & $\mathbf{p}$ & Lower & Top & $\mathbf{R}^{2}$ \\
\hline $\begin{array}{l}\text { Work Stress Scale } \\
\text { (Constant) }\end{array}$ & 4,919 & ,238 & 20,660 & ,000 & 4,449 & 5,389 & \\
\hline Role Conflict Scale &,- 360 & ,041 & $-8,730$ &, 000 &,- 441 &,- 279 & ,370 \\
\hline Role Ambiguity Scale &,- 177 & 045 & $-3,906$ & ,000 &,- 267 &,- 088 & 404 \\
\hline $\begin{array}{l}\text { Knowledge of } \\
\text { Professional Law } \\
\text { and Regulations } \\
\end{array}$ &,- 467 & ,149 & $-3,135$ & ,002 &,- 761 &,- 173 & ,435 \\
\hline
\end{tabular}




\section{DISCUSSION}

It was found that nurses and midwives working in institutions which provide primary Since health institutions are both work environments where service users experience intense stress and service providers experience stress very frequently, there is more work stress in these environments. The excessive workload and the poor determination of duties and responsibilities are among the important factors that cause work stress $(17,18)$.

When the sociodemographic characteristics were examined; it is concluded that married people experience the role ambiguity more than singles. In the study conducted by Yeşilyurt (19) on nurses, a significant difference was found between the scores of role ambiguity according to marital status, but unlike our study, it was concluded that single nurses mostly experienced role ambiguity. Contrary to all these findings, some studies did not find a significant difference between the score of role ambiguity according to marital status (20-23) Married health workers have different roles such as mother, father and spouse compared to single workers in business life. therefore, it is thought that married employees experience more role ambiguity.

It was seen that people who did not like their profession experienced more role ambiguity. Şahin (22) found a significant difference between role ambiguity scores in terms of liking the work environment and found that those who were not satisfied with the work environment experienced the role ambiguity more. It is thought that health workers experience role ambiguity because they do not adopt the roles they are obliged to perform because they do not like their professions.

It was concluded that people who do not have professional law and regulation knowledge experience more role ambiguity. In his study on physicians and nurses, Özkan (21) found a significant difference between role ambiguity scores according to professional law and regulation information, and, contrary to our study, concluded that physicians and nurses with sufficient professional laws and regulations experienced more role ambiguity. The reason for this may be that health workers do not want to learn the roles they are obliged to perform because of dislike of their profession and the duties and responsibilities defined for these roles. As is known, professional laws and regulations determine the duties and responsibilities of individuals. If these rules are not followed, legal problems arise.

It is seen that people who have partial knowledge of professional duties and responsibilities experience more role ambiguity. Similar to our study, Yörükoğlu (24) and Narin (25) concluded that people who partially have professional duty and responsibility knowledge experienced more role ambiguity in their studies. It is thought that people with limited knowledge experience more ambiguity than those who do not.

It was seen that the role conflict was mostly experienced by health personnel between 25-30 years of age. Yeşilyurt (19) found a significant difference between the role conflict scores according to age in the study performed by nurses, and concluded that those who had a role conflict had a maximum age of 49 and older. Topuz (20), Yörükoğlu (24), Şahin (22), Narin (25) and Tarrant (26) did not find a significant difference in their work on role conflict.

Emergency units are the places where the patients health is decided and intervened very quickly. Most of the time, physicians, nurses, emergency medical technicians and ambulance and emergency care technicians provide services to the same patient at the same time. In this 
case, a role conflict may occur. It is thought that it is due to the lack of experience and professional excitement of the employees especially in the 25-30 age range. It is also possible that emergency medical technicians and ambulance and emergency care technicians intervene to the patient alone and away from the hospital.

It is seen that people who do not like their profession experience more role conflict. It is thought that health workers who do not like their profession also experience role conflicts because they do not fully know or adopt the roles they are obliged to do.

It is seen that women experience more work stress than men. Erşan et al. (27) obtained the same result in our study on health workers. Contrary to our results; he it found no significant difference between work stress by gender in their study on health workers of Aslan et al. (28), physicians of Sünter et al. (29), ambulance workers of Tokuç et al. (30), emergency staff of Koç (31), nurses of Laal and Aliramaie (32), ambulance workers of Atan and Tekingündüz (33). It is thought that women experience more work stress than men due to their work in stressintensive units, gender discrimination, sexual harassment, violence, conflict in their roles and responsibilities in their family life and work life.

It was seen that people between 25-30 years experienced more work stress. In the study of Arikan and Karabulut (34), health workers between 26 and 33 years of age and In the study of Koç (31), health workers between 25 and 35 years of age have been found as the most stressful age group. Such a result may be the health care workers due to their early get a job, not being fully aware of their duties and responsibilities, and especially for 112 employees to encounter emergencies outside the hospital and to make quick and accurate decisions in a short time. In addition, it is thought that it is due to the fact that institutions do not fully implement their initiatives to reduce the factors causing work stress.

It was found that those who do not like their profession experience more work stress. In general, individuals who work in a job they do not like may experience situations such as unhappiness, tension, unwillingness to come to work, and desire to quit, and it is inevitable that all of these will cause stress. Therefore, it is thought that health workers who do not like their jobs experience intense work stress.

It was found that people who have partial knowledge of professional laws and regulations experienced more work stress. It is thought that these employees do not know their roles and how they will react in case of an emergency, and because of their lack of professional knowledge, they feel insufficient to make quick and correct decisions in crisis and acute moments and thus experience stress. if health professionals have full knowledge of professional laws and regulations, they become more aware of their duties and responsibilities and act more decisively.

Although there is no study in the literature on the inadequacy of law and regulation knowledge of health workers, in our study; It was observed that work stress was mostly affected by inadequacy in law and regulation knowledge, and respectively role ambiguity and role conflict played an important role in increasing work stress. The emergency department and 112 health workers are often confronted with situations such as making quick and accurate decisions about the patient, responding quickly, and being in direct contact with the relatives of the patients during the emergency. therefore, if problems related to work stress, role conflict and role uncertainty are resolved, confusion that may arise in medical errors and interventions may be eliminated. Better quality and excellent health service can be offered. 


\section{CONCLUSION}

Role conflict, ambiguity and work stress are a serious problem for emergency workers. Because of the great responsibility of saving lives and competing against over time, emergency workers happily accept the stress they experience regardless of the severity of the stress. however, in the long run, the factors that cause this stress reduce the productivity and quality of life of emergency workers. Therefore, deficiencies in the areas where problems are experienced should be identified, the roles of emergency workers should be determined with a sharp limit and the factors that cause stress should be eliminated and areas where they can easily fulfill their responsibilities should be created. There is no such study in the literature including emergency and 112 employees similar to our study. Our goal is to fill this gap in the literature, identify problems and to contribute to the institutions to overcome.

\section{Limitations}

The limitations of the research are that the research is conducted in a single center and evaluated only in terms of sociodemographic features.

\section{Ethical consideration of the study}

During the research, the Human Rights Helsinki Declaration was adhered to. Written permission was obtained from the institutions where research data was collected by applying an information form containing the purpose and scope of the study. Ethics Committee approval was received (Number: 53043469-050.04.04 - Date and Number of Documents: 09/09/2016-E.37542).

\section{Funding}

There is no person / organization that supports the work financially.

\section{Conflict of interest statement}

The authors do not have any interest-based relationships.

\section{Acknowledgments}

We would like to thank all healthcare professionals who participated in our study and supported them.

\section{REFERENCES}

1. Dussault, G., \& Dubois, C.-A. (2003). Human resources for health policies: a critical component in health policies. Human resources for health, $1(1), 1$.

2. Akboğa, N. C. (1999). Bölge hastanelerinde hemşirelik hizmetlerinin yönetsel organizasyonu açısından karşılaştırılması.

3. Quaal, S. J. (1999). Clinical nurse specialist: role restructuring to advanced practice registered nurse. Critical care nursing quarterly, 21(4), 37-49.

4. Yörükoğlu, S. (2008). Özel bir hastanede çalışan sağllk personelinin rol çatışması, rol belirsizliği ve tükenmişlik düzeylerinin belirlenmesi. Sağlık Bilimleri Enstitüsü. 
5. Nakajima, Ş. (2016). Endişesiz ilaçsız. İstanbul: Doğan Novus Yayınevi.

6. Harris, P. E. (1989). The nurse stress index. Work \& Stress, 3(4), 335-346.

7. Isenberg, D. L., \& Van Gelder, C. M. (2011). Occupational illness and injury in prehospital care personnel. Occupational Emergency Medicine. Oxford, UK: WileyBlackwell, 162-174.

8. Borda, R. G., \& Norman, I. J. (1997). Factors influencing turnover and absence of nurses: a research review. International journal of nursing studies, 34(6), 385-394.

9. Crabbe, J., Bowley, D., Boffard, K., Alexander, D. A., \& Klein, S. (2004). Are health professionals getting caught in the crossfire? The personal implications of caring for trauma victims. Emergency Medicine Journal, 21(5), 568-572.

10. Kilcoyne, M., \& Dowling, M. (2007). Working in an overcrowded accident and emergency department: nurses' narratives. Australian Journal of Advanced Nursing, The, 25(2), 21.

11. Adriaenssens, J., De Gucht, V., \& Maes, S. (2015). Causes and consequences of occupational stress in emergency nurses, a longitudinal study. Journal of nursing management, 23(3), 346-358.

12. Browning, L., Ryan, C. S., Thomas, S., Greenberg, M., \& Rolniak, S. (2007). Nursing specialty and burnout. Psychology, Health \& Medicine, 12(2), 148-154.

13. Potter, C. (2006). To what extent do nurses and physicians working within the emergency department experience burnout: A review of the literature. Australasian Emergency Nursing Journal, 9(2), 57-64.

14. Rizzo, J. R., House, R. J., \& Lirtzman, S. I. (1970). Role conflict and ambiguity in complex organizations. Administrative science quarterly, 150-163.

15. Tunc, T. (2008). Doktor ve hemşirelerde tükenmişlik ile rol çatışması ve rol belirsizliği arasındaki ilişki: bir üniversite hastanesi örneği. Sakarya Üniversitesi Sosyal Bilimler Enstitüsü, Yayınlanmamış Yüksek Lisans Tezi, Sakarya.

16. Baltaş, A., \& Baltaş, Z. (2012). Stres ve Basa Çıkma Yolları. 28. Basım İstanbul: Remzi Kitabevi.

17. Akbal Ergün, Y. (2014). Çatışma Yönetimi. Tatar Baykal, Ü. Ercan Türkmen, E. (ed.), Hemşirelik hizmetleri yönetimi kitabı. (ss.182-183). İstanbul: Akademi Kitabevi.

18. Yazıcı Altuntaş, S. (2014). Stres Yönetimi. Tatar Baykal, Ü. Ercan Türkmen, E. (ed.), Hemşirelik hizmetleri yönetimi kitabı. (ss.667-668). İstanbul: Akademi Kitabevi.

19. Yeşilyurt, T. (2009). Hemşirelerde rol çatışması ve rol belirsizliğinin iş stresi ve iş doyumuna etkisi. Ístanbul Üniversitesi Sağlık Bilimleri Enstitüsü Yüksek Lisans Tezi. Istanbul.

20. Topuz, A. (2006). Hemşirelerde rol çatışması ve rol belirsizliği, iş stresi ve aralarındaki ilişkinin belirlenmesi. Unpublished Master Dissertation, Cumhuriyet University, Health Sciences Institute, Sivas, Turkey.

21. Özkan, Ş. (2008). Rol çatışması ve rol belirsizliğinin hekim ve hemşirelerin tükenmişlik düzeyleri üzerine olan etkileri. Hacettepe Üniversitesi, Ankara, 77-87.

22. Şahin DY, Önder ÖR. (2009). Ankara Keçiören Ĕ̆itim ve Araştırma Hastanesi hemşirelerinin rol çatışmast-rol belirsizliği ve tükenmişlik durumları. Ankara Üniversitesi Sağl1k Bilimleri Enstitüsü.

23. Akdaş, E. (2015). Hemşirelerde rol çatışması ve rol belirsizliğinin tükenmişlik ve iş doyumuna etkisi: Yayımlanmamış yüksek lisans tezi. Beykent Üniversitesi Sosyal Bilimler Enstitüsü.

24. Yörükoğlu, S. (2008). Özel bir hastanede çalışan sağlık personelinin rol çatışması, rol belirsizliği ve tükenmişlik düzeylerinin belirlenmesi. Sağl1k Bilimleri Enstitüsü. 
25. Narin, Y. (2010). İstanbul İlinde bir eğitim araştırma hastanesinde çalışan hemşirelerin rol çatışması, iş doyumu ve stres düzeylerinin belirlenmesi. Sağlık Bilimleri Enstitüsü.

26. Tarrant, T., \& Sabo, C. E. (2010). Role conflict, role ambiguity, and job satisfaction in nurse executives. Nursing Administration Quarterly, 34(1), 72-82.

27. Erşan, E. E., Yıldırım, G., Doğan, O., \& Doğan, S. (2013). Sağlık çalışanlarının iş doyumu ve algılanan iş stresi ile aralarındaki ilişkinin incelenmesi. Anadolu Psikiyatri Dergisi, 14(2), 115-121.

28. Aslan, S. H., Alparslan, Z. N., Aslan, R. O., Kesepara, C., \& Ünal, M. (1998). İşe bağlı gerginlik ölçeğinin sağlık alanında çalışanlarda geçerlik ve güvenirliği. Düşünen Adam, 11(2), 4-8.

29. Sünter, A. T., Canbaz, S., Dabak, Ş., Öz, H., \& Pekșen, Y. (2006). Pratisyen hekimlerde tükenmişlik, işe bağlı gerginlik ve iş doyumu düzeyleri. Genel Tip Dergisi, 16(1), 9-14.

30. Tokuç, B., Turunç, Y., \& Ekuklu, G. (2011). Edirne'de ambulans çalişanlarinin anksiyete, depresyon ve işe bağli gerginlik düzeyleri. TTB Mesleki Sağlık ve Güvenlik Dergisi, 11(42), 39-44.

31. Koç, Ş. (2009). Sağlık Çalışanlarında İş Stresi Acil Servis Örneği. Yayınlanmamış Yüksek Lisans Tezi, Beykent Üniversitesi Sosyal Bilimler Enstitüsü, İsletme Yönetimi Anabilim Dal, İstanbul.

32. Laal, M., \& Aliramaie, N. (2010). Nursing and coping with stress. International Journal of Collaborative Research on Internal Medicine \& Public Health, 2(5), 0-0.

33. Atan M, Tekingündüz S. (2014). Ambulans çalışanlarının (112) tükenmişlik, algilanan iş stresi ve iş tatminlerinin kişisel özelliklere göre incelenmesi. Social Sciences, 9(3), 54-69.

34. Arıkan, D., \& Karabulut, N. (2004). Hemşirelerde işe bağli gerginlik ve bunu etkileyen faktörlerin belirlenmesi. Anadolu Hemşirelik ve Sağllk Bilimleri Dergisi, $7(1)$. 